\title{
FAMILY AS VALUE. THE MODEL OF A FAMILY MOULDED BY GRADUATING STUDENTS
}

\begin{abstract}
Family is the most important value, which is present in the life of each individual. It was confirmed by research conducted among graduating students of the secondary school, who placed family and love at the highest place in the hierarchy of values, claiming that it is [at the same time] a fundamental factor of well-functioning matrimony. Graduating students have plans connected with entering into matrimony.

The studies conducted revealed that almost each of the respondents is going to establish [one's own] family and have progeny. The plans of respondents as for matrimony and procreation concerned mainly the nature of their relationship, preferred type of their relationship, factors that are crucial for entering into matrimony, features that a husband-or wife-to-be should possess, age at which the respondents plan to have children, and the number of the children.

Analysis of the research revealed that matrimony is treated very seriously by the respondents, and that they are planning to enter it [not until] graduating and obtaining a job offer. Love, stability of life, and willingness to have progeny are the factors that are the most influential as for moulding the family model among graduating students. On the other hand a lack of decision concerning establishing a family is directly connected with the emergence of such factors as betrayal, uncertainty of choosing [the right] partner, poor health condition, obtaining education, attractive job.
\end{abstract}

Keywords: family; matrimony; plans for matrimony and procreation; preferences; values

\section{INTRODUCTION}

Psychologists, sociologists and educationalists have been analysing family from different aspects since many years. This small group "[...] is a social structure, which consists of several units which are in defined relations to each other, which has its own system of values and norms, which regulate behaviour of units in matters important for the group. Parents and children have defined roles and positions in the internal structure of the family." (Ochmański, 1993, p.118). It is a natural educational environment, in which the major elements are interactions between individual members (Kawula, 1997). In this environment. where a child is brought to the world, grows up, moulds its personality, acquires particular values and role models - undergoes the process of socialization, which prepares it to enter into adulthood. According to J. Szczepański, a family is an educational-cultural institution, which provides maintenance, development of cultural heritage both of an individual, and a community (Kawula, 1997).

Despite the point of view from which a family is analysed, there is one conclusion - it constitutes basic form of functioning of the whole society. It is created by a structuralized and formalized set of units and specific substructures, as well as social microelements and at the same time it is a social institution, which is bound internally with the marital bonds, ties of 
kinship, or adoption and which fulfils a lot of crucial, important, integrated functions towards units and society, which base on controllers which are present in the behavioural culture (Tyszka 2001).

\section{THE AIM OF THE STUDY}

To get to know the hierarchy of values of young people from the graduation classes (pointing out the place of the family in such a hierarchy), marital and procreation plans of students and factors, which could have influence on the decision concerning starting up a family.

\section{MATERIALS AND METHODS}

Family as value is becoming more and more important for young people and in fact it constitutes their system of values. It is a means keeping emotional balance of people, and guaranteeing a sense of safety (Małek, 2004). The emotional contacts in the family shape the predispositions of its members, views, reactions and life attitudes (Dyczewski, 1994).

A family according to John Paul II is a place of introducing basic values, which gives sense to life and harmonious development of emotionality, ability to live in society, dialogue with different cultures, as well as life in tolerance (quotation after: Zarembski). Referring to the statement of John Paul II, one has to state that family is an institution, which educates and satisfies essential human needs. Young people shape their attitudes and values in the family. Within the space of recent years the values of young people have undergone changes. A. Zielińska points out that "[...] social and economic transformations, which occurred in the 90s wrecked enormous havoc in former system of traditional values of young generation." (Zielińska, 1995, p.10). The author points out that the most important values for young people in the 70 s and 80 s were: family life, close relations with people and having friends. On the contrary, in the 90 s only $26 \%$ of young people pointed at the family life as one of the five important values. $49 \%$ of the questioned named getting education and knowledge; $44 \%$ - being free, feeling that one can live in a way one wants; $43 \%$ - protection of natural environment" (Zielińska, 1995).

Although quoted research indicate that family was pushed aside to a further place in the hierarchy of the system of values, it is still highly appreciated by them. The report "Young people 2005", which was prepared by young people together with AIG OFFE and "Gazeta Wyborcza" [one of the national daily papers] confirms it fully. The statements of young people concerning the values which regard family indicate that: "future is a husband, wife, children, flat, car, good work, friends and so much money that if there is necessity one can lead a modest, calm life. Decision concerning starting up a family is postponed to the future" (Zaremba, 2008, p.108).

The research ${ }^{1}$ was conducted with a group of 70 pupils from graduation classes from the Complex of Schools in Pasłęk ${ }^{2}-40$ women (57,1\%) and 30 men (42,9\%) took part it the research. These were pupils from the graduation classes aged 18-21. Among the examined the biggest

\footnotetext{
${ }^{1}$ The research was conducted by a student, who was preparing her thesis entitled "Model of a family in the eyes of contemporary young people" under my supervision. The research was expanded with additional variables.

2 The Complex of Schools in Pasłęk includes: the High School and Vocational School. Because of the small number of students, who attended school at the time of the conduction of the research to the graduation classes of the high school (the research was conducted in 2009), as well as problems with questioning all students of the high schools (headmasters of the schools did not want to give consent to the conduction of the research), 70 students at the age of 18-21 took part in the research. Pasłęk is a small city located in the Varmian Masurian Voivodeship. It is located on the North edge of the Ilawskie Lake District. At the end of 2010 there were 12067 citizens in the city.
} 
group was formed by persons, who were aged $19(61,4 \%)$, more often these were women $(38,5 \%)$, than men (22,9\%), next groups include persons at the age of $18(31,5 \%), 20(5,7 \%), 21(1,4 \%)$.

In the research a survey questionnaire consisted of a certificate and 17 closed and partly closed questions. These questions facilitated the receiving of answers, in order to answer the questions put by the complex aim of the research.

\section{RESULTS}

The analysis of empirical material proved that more than half of the questioned $(52,9 \%)$ are citizens of villages. $47,1 \%$ of respondents live in the city. Most of the questioned $(57,1 \%)$ come from full families, in which both parents are present. They create a two generation family, which is a dominating form of family life regardless of the respondents' place of residence. About $20 \%$ of the questioned is brought up in incomplete families - about $16 \%$ without the father, and the rest - without the mother. $28,7 \%$ of the respondents are brought up in multigenerational families.

An essential element of the family composition is also the number of siblings. It turned out that $28,6 \%$ of the questioned have one brother or sister, $27,1 \%$ have two siblings, $17,1 \%-$ three, $12,9 \%$ of the respondents are the only children and $14,3 \%$ have more than three siblings. more young people from the city $(17,1 \%)$ are more likely to have one brother or sister, than the ones from the village $(11,3 \%)$. The only children are more often from the city, than village.

\section{Family as a value for the young people from graduation classes}

Family is the biggest value in the life of every man. This research has also proved it. For $43 \%$ of the respondents, $(24,4 \%$ women, and $18,6 \%$ men; $24,3 \%$ residents of cities, and $18,7 \%$ of villages) family is at the higher place in the hierarchy of values, in fact, it is on the first place. On the second place $24,3 \%$ of the respondents place love, which is more often chosen by men $(14,3 \%)$ and the residents of cities $(17,1 \%)$, on the third place is health $-22,8 \%$, of both women and men obtained the same percentage index $-11,4 \%$. On the following places there is friendship, which is located on the fourth place by $34,3 \%$ of the questioned young people, faith is on the fifth position $-37,2 \%$ of the questioned placed it there. On the last, sixth place, according to $60 \%$ of the respondents is money.

As it results from the data presented in Tables 1 and 2, young people from the graduation classes locate family and love on very high places in the hierarchy, which in their opinion is a basic foundation of a good marriage. Both men and women placed these values in the leading positions. The research, which was conducted by different authors (Cieszejko, 2008; Zaremba, 2008; Truszkowska, 2008; Biernat, 2004; Porańczyk, 2005; Lezhnina 2011; Tikhomirova 2011; Edgar-Smith \& Wozniak, 2010) confirm that these values are chosen by young people. Family for young people is very important, regardless whether it is a multigenerational family or a onegeneration family. It just has to exist in the life of every indovidual; it gives sense to his/her life, what is confirmed by the results of the research in which family is in the leading place in the hierarchy of values.

The examined youth, as well as respondents of other authors place hedonistic values in the lowest positions of the hierarchy of values, which include mainly money. It is the next evidence, which proves that family is the most important value in the life of every individual. 
Table 1. Values recognized by young people from the graduation classes according to the sex

\begin{tabular}{|c|c|c|c|c|c|c|c|c|c|c|c|c|c|c|c|c|c|c|c|c|c|c|c|c|}
\hline \multirow[b]{3}{*}{ Values } & \multicolumn{4}{|c|}{ PLACE I } & \multicolumn{4}{|c|}{ PLACE II } & \multicolumn{4}{|c|}{ PLACE III } & \multicolumn{4}{|c|}{ PLACE IV } & \multicolumn{4}{|c|}{ PLACE V } & \multicolumn{4}{|c|}{ PLACE VI } \\
\hline & \multicolumn{2}{|c|}{ Men } & \multicolumn{2}{|c|}{ Women } & \multicolumn{2}{|c|}{ Men } & \multicolumn{2}{|c|}{ Women } & \multicolumn{2}{|c|}{ Men } & \multicolumn{2}{|c|}{ Women } & \multicolumn{2}{|c|}{ Men } & \multicolumn{2}{|c|}{ Women } & \multicolumn{2}{|c|}{ Men } & \multicolumn{2}{|c|}{ Women } & \multicolumn{2}{|c|}{ Men } & \multicolumn{2}{|c|}{ Women } \\
\hline & $\mathrm{N}$ & $\%$ & $\mathrm{~N}$ & $\%$ & $\mathrm{~N}$ & $\%$ & $\mathrm{~N}$ & $\%$ & $\mathrm{~N}$ & $\%$ & $N$ & $\%$ & $\mathrm{~N}$ & $\%$ & $\mathrm{~N}$ & $\%$ & $\mathrm{~N}$ & $\%$ & $\mathrm{~N}$ & $\%$ & $\mathrm{~N}$ & $\%$ & $N$ & $\%$ \\
\hline Family & 13 & 18,6 & 17 & 24,4 & 7 & 10,0 & 13 & 18,6 & 3 & 4,3 & 7 & 10,0 & 5 & 7,1 & 3 & 4,3 & 1 & 1,4 & 0 & 0 & 1 & 1,4 & 0 & 0 \\
\hline L & 7 & 10,0 & 16 & 22,7 & 10 & 14,3 & 7 & 10,0 & 6 & 8,6 & 11 & 15,7 & 4 & 5,7 & 5 & 1 & 1 & 1,4 & 1 & 1,4 & 2 & 2,9 & 0 & 0 \\
\hline $\mathrm{He}$ & 2 & 2,9 & 5 & 7,1 & 5 & 7,1 & 11 & 15,7 & 8 & 11,4 & 8 & 11,4 & 3 & 7,1 & 9 & 12,9 & 9 & 12,9 & 4 & 5,7 & 1 & 1,4 & 3 & 4,3 \\
\hline Frie & 0 & 0 & 0 & 0 & 5 & 7,1 & 5 & 7,1 & 7 & 10,0 & 9 & 12,9 & 10 & 14,3 & 14 & 20,0 & 4 & 5,7 & 10 & 14,3 & 4 & 5,7 & 2 & 2,9 \\
\hline $\mathrm{Fr}$ & 1 & 1,4 & 2 & 2,9 & 3 & 4,3 & 3 & 4,3 & 4 & 5,7 & 4 & 5,7 & 5 & 7,1 & 7 & 10,0 & 12 & 17,2 & 14 & 20,0 & 5 & 7,1 & 10 & 14,3 \\
\hline Mon & $t$ & 10,0 & 0 & 0 & 0 & 0 & 1 & 1,4 & 2 & 2,9 & 1 & 1,4 & 1 & 1,4 & 2 & 2,9 & 3 & 4,3 & 11 & 15,7 & 17 & 24,4 & 25 & 35,6 \\
\hline Together & 30 & 42,9 & 40 & 57,1 & 30 & 42,9 & 40 & 57,1 & 30 & 42,9 & 40 & 57,1 & 30 & 42,9 & 40 & 57,1 & 30 & 42,9 & 40 & 57,1 & 30 & 42,9 & 40 & 57,1 \\
\hline
\end{tabular}

Percentage does not sum up to 100,0 , because the questioned had to put values in the order from the most important to the least important ones. The percentage index for the data was counted for the group of the questioned $(\mathrm{N}=70)$.

Table 2. Values recognized by young people from the graduation classes according to the place of residence

\begin{tabular}{|c|c|c|c|c|c|c|c|c|c|c|c|c|c|c|c|c|c|c|c|c|c|c|c|c|}
\hline \multirow[b]{3}{*}{ Values } & \multicolumn{4}{|c|}{ PLACE I } & \multicolumn{4}{|c|}{ PLACE II } & \multicolumn{4}{|c|}{ PLACE III } & \multicolumn{4}{|c|}{ PLACE IV } & \multicolumn{4}{|c|}{ PLACE V } & \multicolumn{4}{|c|}{ PLACE VI } \\
\hline & \multicolumn{2}{|c|}{ City } & \multicolumn{2}{|c|}{ Village } & \multicolumn{2}{|c|}{ City } & \multicolumn{2}{|c|}{ Village } & \multicolumn{2}{|c|}{ City } & \multicolumn{2}{|c|}{ Village } & \multicolumn{2}{|c|}{ City } & \multicolumn{2}{|c|}{ Village } & \multicolumn{2}{|c|}{ City } & \multicolumn{2}{|c|}{ Village } & \multicolumn{2}{|c|}{ City } & \multicolumn{2}{|c|}{ Village } \\
\hline & $\mathrm{N}$ & $\%$ & $\mathrm{~N}$ & $\%$ & $\mathrm{~N}$ & $\%$ & $\mathrm{~N}$ & 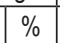 & 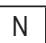 & $\%$ & $\mathrm{~N}$ & $\%$ & $\mathrm{~N}$ & $\%$ & $\mathrm{~N}$ & 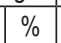 & $\mathrm{N}$ & $\%$ & $\mathrm{~N}$ & & $\mathrm{~N}$ & $\%$ & $\mathrm{~N}$ & $\%$ \\
\hline Family & 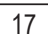 & 24,3 & 13 & 18,7 & 4 & 5,7 & 16 & 22,9 & 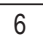 & 6 & 4 & 5,7 & 0 & 8,6 & 2 & ,9 & 0 & 0 & 1 & 1,4 & 0 & 0 & 1 & 1,4 \\
\hline Love & 11 & 15,7 & 12 & 17,2 & 12 & 17,1 & 5 & 7,1 & & 7,1 & 12 & 17,2 & 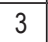 & 4,2 & 6 & 6 & 1 & 1,4 & 1 & 1,4 & 1 & 1,4 & 1 & 1,4 \\
\hline Heal & 1 & 4 & 6 & 8,6 & 10 & 14,3 & 6 & 8,6 & & 8,6 & 10 & 14,3 & 10 & 14,3 & 4 & 5,7 & 4 & 5,7 & y & 12,9 & 2 & 2,9 & 2 & 2,9 \\
\hline Frie & 0 & 0 & 0 & 0 & 4 & 5,7 & 6 & , & 11 & 15,7 & 5 & 7,1 & 8 & $\mid 11,4$ & 16 & 22,8 & 7 & 10 & 7 & 10,0 & 3 & 4,3 & 3 & 4,3 \\
\hline it & 2 & 2,9 & 1 & 14 & 2 & 2,9 & 4 & ,7 & 4 & 5,7 & 4 & 5,7 & 6 & 8,6 & 6 & 8,6 & 16 & 22,9 & 10 & 14,3 & 3 & 4,3 & 12 & 17,2 \\
\hline Men & 2 & 2,9 & 5 & 7,1 & I & 1, & 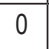 & . & & 4 & 2 & 29 & 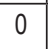 & 0 & 3 & 3 & 5 & 7,1 & 9 & 12,9 & 24 & 34,2 & 18 & $25,7 \mid$ \\
\hline gether & 33 & 47,1 & 37 & 52,9 & 00 & 47,1 & 37 & 2,9 & 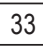 & 7,1 & 37 & 52,9 & 33 & 47,1 & 37 & 52, & 33 & 47,1 & 37 & 52,9 & 33 & 47,1 & 37 & 52,9 \\
\hline
\end{tabular}

Percentage does not sum up to 100,0 , because the questioned had to put values in the order from the most important to the least important ones. The percentage index for the data was counted for the group of the questioned $(\mathrm{N}=70)$.

\section{Marital and procreational plans of young people}

One has been asked questions concerning the essence of marriage, prefered kind of relationship, factors, which induce people to enter the state of matrimony, the traits, which should be possessed by the future husband/wife, the age at which the questioned plan to have children and the number of offspring, for determining marital and procreational plans.

A large percentage of respondents want to live in a formal matrimony $(81,5 \%)$. There are more women (50\%) (men constitute 31,5\%) among this group of respondents. These are persons, who live both in cities and villages. The percentage index for persons, who want to live in a formal relationship and come from cites reached $41,5 \%$, whereas for people living in villages it was $40 \%$. 
Quite substantial percentage of respondents cared for life in the so-called partnership (15,7\%). More often such answer was given by men $(8,6 \%)$ (women constituted $7,1 \%$ ). Analysing the place of residence of the people, who want to live in a partnership in future, one has to indicate that more often these are young people, who live in the village $(11,5 \%)$, than in the city $(4,3 \%)$. Young people also prefer to live in the so-called loose relationships with numerous partners (mainly men living in the villages $1,4 \%$ ) and life in singlehood (men living in the villages $1,4 \%$ ).

Persons who prefer living in a formal relationship in future understand the essence of marriage as: Legalized relationship of man and woman, who decide to spend life together, and one person does not limit another. 37,1\% of women and $28,7 \%$ of the people who live in the village interpret the essence of marriage in such a way. For $45,8 \%$ of respondents the essence of life is: Unity, inseparability, hard work, sacrifices, total devotion to each other. Among the people, who prefer such kind of relationship 25,8\% were men and 20\% - women. The same percentage was demonstrated by the questioned from villages and cites, that is $22,8 \%$. Only a small percentage of the respondents pointed out that marriage is: Legalized relationship of man and woman, who decide to spend life together because of the welfare of a child. Such interpretation was presented mainly by men $(2,8 \%)$ who lived both in the city $(1,4 \%)$ and village $(1,4 \%)$.

An important assumption of the analysis of the research was to better know the factors, which influence the decision of entering the state of matrimony in future. During the research the questioned respondents were asked to point out to three most important factors. The results of this research show that the main factor, which is decisive as far as entering the state of matrimony is concerned, in the opinion of both women and men, is love. This factor was more often pointed out by women $(45,7 \%)$, than men (24,3\%). Among the persons who point out love were respondents living both in the city $(35,7 \%)$, and village $(34,3 \%)$. Next factors, which were important for the questioned, which have influence on the decision concerning the entering the state of matrimony were also life stability (28,6\% women, $11,6 \%$ men; $24,2 \%$ residents of the city, $15,8 \%$ residents of the village) and willingness to have children (22,9\% women, $10 \%$ men; $18,5 \%$ respondents from cities, $14,4 \%$ respondents from villages). Sexual satisfaction or length of relationship, fear of solitude, common interests, as well as the attractiveness of the partner were assessed as less important.

Analysing the above-mentioned factors which the respondents pointed out, one can notice that they are important for women and persons living in cities. One can come to a conclusion that women living in cities aim at formalizing the matrimony, in which love and offsprings are the main foundations which unite the relationship. The previous research of the author (PrzybyszZaremba, 2009) proves that love and attachment to a partner are the main factors on which a "real" relationship should be based - it is the foundation of every family, which functions "correctly."

Love is pointed out by respondents as main "factor" which is in the relationship, which is treated as source of happiness, indicator of the quality of marriage (Bakiera, 2009). It is important that love is mature - "[...] mature marital love is the sign of development of the loving person and a factor of development of the loved person" (Bakiera, 2009, 35). It is fully confirmed by the words of Pope Benedict XVI "[...] love, which is eternal, fundamental, tenacious, devoted, full of sacrifice and focused on the wealth of the second person constitutes a foundation of a family" (Benedict XVIth, 2007, p.12).

The questioned students from the high school also determined traits, which should be possessed by their future partners, with whom they would like to start up a family. The research showed small differences between the traits enumerated by men and women, According to women 
a future husband should be characterized by: faithfulness $52,8 \%$, honesty $41,4 \%$, protectiveness $30 \%$, understanding $20 \%$, and physical attractiveness $11,4 \%$. Men in turn pointed out such traits as: faithfulness $34,3 \%$, and physical attractiveness $(27,2 \%)$. Men also pointed out understanding $(18,6 \%)$ and protectiveness $(10 \%)$.

Examining these traits closer one can notice that for men a very important trait is the attractiveness of the partner, which is listed by them as the third trait. In the opinion of women this trait is on the fifth place. It can be assumed that for women it is least important. However, both the questioned living in the city and village point out the importance of the partner possessing such traits as: faithfulness $-44,2 \%$ of the respondents from cities and $42,9 \%$ - from villages; honesty $-35,7 \%$ of the respondents from cities and, $32,9 \%$ of the respondents from villages. The conducted research also showed substantial differences in the analysis of the rest of the traits, which should be possessed by the future partner, with whom the respondents would like to start up a family in future. These differences were closely related to the place of residence. In this way for the respondents living in the city quite important were also the following traits: understanding of the partner $(17,1 \%)$, protectiveness $(15,7 \%)$ and physical attractiveness $(15,7 \%)$, whereas the respondents living in villages highly estimated such traits as: protectiveness $(24,3 \%)$, physical attractiveness $(22,9 \%)$ and understanding $(21,4 \%)$.

The traits presented by the respondents which should be possessed by the partner prove that young people from the graduation classes treat the creation of their relationship very seriously. The imagined model of the family is based on love, faithfulness, honesty and protectiveness, which prove that they are fully mature and ready to start up a family. The evidence is also the enumeration of such traits as good work and tolerance, which are valued as least important.

The model, which is mainly created by young people from the graduation classes is mainly based on "partner cooperation" which means that all decisions, which are made in the family are made by both partners, both of them devote an equal amount of time to professional work, house and children (51,4\% of women and nearly $33 \%$ of men; $43 \%$ of respondents from village and $41,3 \%$ from city). In the opinion of nearly $76 \%$ of the respondents, a woman should work professionally and take care of the house (48,6\% women and more than $27 \%$ men; $40 \%$ of the respondents from cities $35,7 \%$ of the respondents from villages). For $90 \%$ of the respondents the same tasks should be preformed by men - they should work and take care of the house (nearly $53 \%$ of women and $37,2 \%$ of men; nearly $49 \%$ of the people living in the village and $41,4 \%$ of the respondents from city).

Young people create a partnership model of a family, which is based on the subjectivity of both partners which appears in three spheres of life: feeling of self-subjectivity, in relations with the outer world and in social relations (Willan-Horla, 2008).

The marital and procreational plans of pupils from the graduation classes of high schools also bind with the willingness of having offspring. Among the respondents only a small percentage $(2,9 \%)$ pointed out that they do not intend to have children in future. For the rest of the group having children in a relationship constitutes its fulfillment, strengthens it and is also fruit of love. Despite the fact that about $13 \%$ of the respondents pointed out that quite an important factor which helps them to make the decision of having children in future is anxiety of not having care when they are old. Among the respondents nearly $60 \%$ plan to have two children $(41,4 \%$ of women $18,6 \%$ of men; nearly $33 \%$ of the residents of the city and $27,1 \%$ of the people living in the village). $14,3 \%$ of the respondents plan to have three children $-7,1 \%$ of them are women and $7,1 \%$ are men, $10 \%$ are the residents of the village and $4,3 \%$ are the residents of the city. 
Young people from the graduation classes create a model of a family closely related with economic changes which are present in the country. It can be proved by future procreational plans of respondents. Nearly $63 \%$ of them state that they want to have children after graduating from the university (when they finish higher education), and nearly $33 \%$ after "making" professional carrier. Both men and women, who live in the city and village say that the decision o having children depends on these factors. Only $1,4 \%$ of the questioned men stated that they would be able to (they would manage to) have children during the process of education. There is a question: who will play a tutorial and educational role in such a relationship? On the basis of observations one can state that it is the woman who usually does all duties which are connected to bringing up children. She very often resigns from her own educational and professional plans, just to take care of the child. Moreover there can be situations in which the child is an obstacle to "making" the professional careers of both partners and very often it leads to situations in which the woman has an abortion, or abandons her baby. Sometimes the partner kills his pregnant wife, because he thinks that unintentional pregnancy could destroy his life.

Presented research results are reflected in the Report of 2007 "Views and attitudes of young people concerning values, aims and models of the family, functioning of marriage, marital roles and questions concerning having and bringing up children." It results from the report that "among young people there is a partnership vision of marriage based on good contact and trust, equal division of household duties, as well as bringing up children by both parents on equal rights. The main motives of entering the state of matrimony, similarly as in the research presented in this paper are: love, desire to have children, and need of sense of safety. In the opinion of young people marriage is to deepen sense of intimacy, self-knowledge and self-development. Its basis has to be constituted by: mutual respect and tolerance, emotional and sexual faithfulness, ability to forgive, satisfying sexual life and mutual will of having children" (Biernat, Sobierajski, 2007, pp.18-23).

\section{Lack of decision on starting up a family}

A crucial element, which indicates that family is the most important value for young people is presenting factors, which can have influence on not taking up family roles. The conducted research proved that for $74,3 \%$ of the respondents $(45,7 \%$ of women and $28,6 \%$ of men; $40 \%$ living in the village and 34,3\% living in the city) betrayal of the partner is the main factor which influences the lack of decision concerning entering the state of matrimony. Such factors as doubts concerning the choice of partner (64,3\% of all respondents) $(42,8 \%$ women and $21,5 \%$ men; $32,9 \%$ of the residents of the village $31,5 \%$ of the persons living in the city), difficult financial situation (64,3\%) (32,8\% women and $31,5 \%$ men; $41,5 \%$ of the residents of the village $22,8 \%$ of the persons living in the city) bad health condition $(52,9 \%)(27,2 \%$ women and $25,7 \%$ men; $31,5 \%$ of the residents of the village $21,4 \%$ of the persons living in the city), getting education $(18,6 \%)(12,9 \%$ women and $5,7 \%$ men; $11,4 \%$ of the residents of the village $7,2 \%$ of the persons living in the city) and attractive work place (17,1\%) (10\% women and 7,1\% men; $11,4 \%$ of the residents of the village $5,7 \%$ of the persons living in the city) hold young people back from the decision of entering the state of matrimony.

The above-presented factors confirm the fact that family is very important for young people. It cannot be built on lie, uncertainty and lack of trust. This data show some kind of distance and carefulness in taking up marital-procreational roles by the respondents, which is regarded as very positive in the contemporary world.

Plans connected with the decision of starting up a family are pushed aside. It can be presumed that the postponing of this decision is influenced by a continuous increase of the number 
of divorces. In the countries of the European Union there are about 1,062,500 divorces, which means that every other marriage falls apart (see Przybysz-Zaremba, 2008, 301-302). According to the data of the Central Statistic Office of Belarus in the period from January to August 2010 only 49,700 of weddings were registered, and in Russia nearly $50 \%$ of adults have been in an unsuccessful relationship (i.e., they were in separation, divorced or in unsuccessful informal relationship) (Lezhnina, 2011).

\section{CONCLUSIONS}

The presented research lets us state that despite substantial social and economic changes family is still in the leading position in the hierarchy of the young generation. It is unavoidable however that up to date the traditional model of the family is pushed aside by the so-called partnership model of the family, which dominates in the contemporary world ${ }^{3}$ (Quotation of: Willan-Horla, 2008, 148). The young people living in the world of constant change and transformation are forced to take a lot of actions at the same time: e.g., work professionally, raise their qualifications, take care of the house, bring up children etc. Life in the constant "rush" made them create a new, modern model of the family which is based on partnership, love, cooperation and trust - conducted research proved it fully.

The presented analysis of the research points out that for the model of the family created by the young people various factors have substantial influence, such as for example:

- Decision on entering the state of matrimony. The respondents who decide to enter the state of matrimony in future will be guided by love to their partner, life stability and willingness of having children.

- The preferred partner, with whom one wants to start up a family in future should possess such traits as: faithfulness, honesty, protectiveness, understanding and be physically attractive.

- Marital and procreational plans are to be carried out only after getting higher education, and sometimes even after achieving some professional prestige by the respondents.

- Lack of decision concerning starting up a family is foremost bound with betrayal by the partner and doubts concerning the choice of the partner.

Summing up one has to state that young people from graduation classes perceive their future life connected with starting their own family very clear-headedly. It is proved by the age at which young people want to have children. It is the next evidence, which proves that family is the most important value for young people.

\section{REFERENCES}

Bakiera, L. (2009). Value of the marriage in the development of an adult. In B. Harwas-Napierała (Ed.), The family as the value in the development of the man. Poznań: Scientific Publishers of the Adam Mickiewicz University. (in Polish).

Benedict XVIth (2007). Let the Religious House be a heart of your city. Speech during the meeting with citizens. Loreto 02 SEP 2007 L'Osservatore Romano, 10-11. (in Polish).

Biernat, T. (2004). The family and the family upbringing in the opinion of elder young people. Bringing up Day by Day, 12. (in Polish).

Biernat, T., Sobierajski, P. (2007). Young people towards the marriage and the family. Report of research. Torun: Publication of the Nicolaus Copernicus University. (in Polish).

$359,1 \%$ of Poles accept and support partnership family model. 
Cieszejko, M. (2008). Contemporary value, and the marital-family plans of young people. In W.Muszyński (Ed.), Love. The faithfulness and the honesty on crossroads of the present. Shapes of the contemporary family. Torun: Publishing house: Adam Marszałek. (in Polish).

Dyczewski, L. (1994). Family, society, state. Lublin: Publishing house of the Catholic Universityin Lublin. (in Polish).

Edgar-Smith, S. E., Wozniak R. H. (2010). Family relational values in the parent-adolescent relationship. Counselling and Values, 54, 187-200.

Kawula, S. (1997). Pedagogy of the family. Toruń: Publishing house: Adam Marszałek (in Polish).

Lezhnina Iu. P (2011). The family in value orientations. Russian Education and Society, 53(2), 78-92.

Małek, U. (2004). Systems of values of young people and their own decisions on education. The man and the market, 1, Lublin: Learned Society of the Catholic University in Lublin KUL. (in Polish).

Ochmański, M. (1993). The essence of bringing up in the family and the behaviour of the child at the nursery school, Lublin Pedagogic Annual, XXI, 118. (in Polish).

Porańczyk, A. (2005). Values of secondary-school young people. In F. Bereźnicki, \& K.Denek (Ed.), Education of the tomorrow. Szczecin: Publication of the University in Szczecin. (in Polish).

Przybysz-Zaremba, M. (2009). Love in domestic partnerships of students. In W. Muszyński (Ed.), Does a time love itself?. Love in partner and family relationships. Toruń: Publishing house: Adam Marszałek. (in Polish).

Przybysz-Zaremba, M. (2008). Social pathologies of the contemporary family. In W. E. Muszyński Sikora (Ed.), The marriage and the family in postmodernism. Chances - threats - social pathologies. Torun: Publishing house: Adam Marszałek. (in Polish).

Tikhomirova, V.V. (2011). The value orientations and sense of social well-being of the young family. Russian Education and Society, 53(3), 74-86.

Truszkowska, M. (2008). The family as the value in the life of secondary-school young people. Case of one school. In A. W.Janke (Ed.), Family upbringing in theory and in practice. Development of the pedagogical orientation to family. Akapit Educational Publishing House. (in Polish).

Willan-Horla, L. (2008). Do contemporary women need the marriage? In W. Muszyński (Ed.), Love. The faithfulness and the honesty on crossroads of the present. Shapes of the contemporary family. Torun: Publishing house: Adam Marszałek. (in Polish).

Tyszka, Z. (2001). Methodological system of multifaceted integral analysis of the family life. Poznań: Scientific Publishers of the Adam Mickiewicz University. (in Polish).

Zaremba, B. (2008). Family - is it still a value for young people? In W. Muszyński (Ed.), Love. The faithfulness and the honesty on crossroads of the present. Shapes of the contemporary family. Torun Publishing house: Adam Marszałek. (in Polish).

Zarembski, Z. (2009). Family as natural environment for raising children in the teaching of John Paul II (28.12.2009). (in Polish).

Zielińska, A. (1995). For pupils and teachers from the city. Five most important values. The Education and the Dialogue, 4(67), 10. (in Polish).

Assistant Professor Margaret Przybysz-Zaremba

The Institute of Pedagogy and Languages

Address: 82-300 Elblagg, ul. Czerniakowska 23, Poland

Phone: 504802513

E-mail: malgorzata.p_z@interia.pl 